\title{
Effects of Ca Addition on the Mechanical Properties and Corrosion Behavior of ZM21 Wrought Alloys
}

\author{
Jiang Yang ${ }^{1} \cdot$ Jian Peng ${ }^{1,2} \cdot$ Min $\mathrm{Li}^{1} \cdot$ Eric A. Nyberg ${ }^{3} \cdot$ Fu-Sheng Pan ${ }^{1,2}$
}

Received: 19 May 2016/Revised: 19 July 2016/Published online: 13 October 2016

(C) The Chinese Society for Metals and Springer-Verlag Berlin Heidelberg 2016

\begin{abstract}
The microstructures, mechanical properties, and corrosion resistance of ZM21 magnesium alloys with a wide range of calcium (Ca) addition (0.1-1.6 wt\%) were investigated. Results showed that the mechanical properties and corrosion resistance were improved with $\mathrm{Ca}$ addition because of grain refinement and formation of $\mathrm{Ca}_{2} \mathrm{Mg}_{6} \mathrm{Zn}_{3}$. However, these properties were deteriorated when $\mathrm{Ca}$ contents reached $1.6 \mathrm{wt} \%$. The optimal Ca content of alloys was $0.7 \mathrm{wt} \%$; alloy with this $\mathrm{Ca}$ content showed good mechanical performance and corrosion resistance, having a strength of $260 \mathrm{MPa}$, an elongation of $21.5 \%$, and an average weight loss of $0.77 \mathrm{mg} /\left(\mathrm{cm}^{2}\right.$ days $)$.
\end{abstract}

KEY WORDS: Microstructure; Mechanical property; Corrosion resistance; Ca addition; Mg alloy

Available online at http://link.springer.com/journal/40195

Jian Peng

jpeng@cqu.edu.cn

Jiang Yang

sallyyangj@163.com

Min Li

20140902036@cqu.edu.cn

Eric A. Nyberg

eric.nyberg@pnnl.gov

Fu-Sheng Pan

fspan@cqu.edu.cn

1 State Key Laboratory of Mechanical Transmission, College of Materials Science and Engineering, Chongqing University, Chongqing 400044, China

2 Chongqing Academy of Science and Technology, Chongqing 401123, China

3 Pacific Northwest National Laboratory, Richland, WA 99354, USA

\section{Introduction}

Magnesium and its alloys, which possess the excellent properties of low density, high specific strength, high specific stiffness, good damping characteristic, and easy returnability, have been widely utilized in aircraft, electronic and automotive industries [1]. Among magnesium alloys, the $\mathrm{Mg}-\mathrm{Zn}-\mathrm{Mn}$ alloys have gained more potential interests due to their excellent mechanical properties, costeffectiveness for manufacturing, and good deformation characteristics during high-speed extrusion [2, 3]. However, poor corrosion resistance is one of the major obstacles for the wide application of magnesium alloys, especially in application of the aggressive environments like sea water $[4,5]$. The main reason of poor corrosion resistance lies in as follows: (1) when contacting aqueous solution, magnesium is easy to dissolve to form hydroxide $\left(\mathrm{Mg}(\mathrm{OH})_{2}\right)$ because of the negative electrochemical potential $\left(-2.37 V_{\mathrm{SHE}}\right)[6,7]$. And the hydroxide above is unstable to act as the passive film [8]. (2) The internal galvanic corrosion occurs for the presence of the intermetallic phases and the noble impurity elements like $\mathrm{Fe}, \mathrm{Ni}$, and $\mathrm{Cu}$ $[9,10]$. 
Some researchers indicated that the addition of alkaline earth element calcium (Ca) was an effective way to improve the strength and corrosion resistance of magnesium alloys [11-15]. Ca is an inexpensive microalloying element, which is widely applied to magnesium alloys [16]. Somekawa and Toshi [17] developed a $\mathrm{Mg}-4.7 \mathrm{Zn}-0.5 \mathrm{Ca}$ alloy with a high yield strength of $291 \mathrm{MPa}$; in this alloy, $\mathrm{Ca}$ contributed to both grain refinement and formation of spherical precipitates. Zhang et al. [18] found that addition of $\mathrm{Ca}$ to $\mathrm{Mg}-\mathrm{Zn}$ alloys results in the increase in elongation and weak extrusion textures. Hofstetter et al. [19] and Zhang and Yang [20] investigated the effects of Ca on the corrosion resistance of as-cast ZM61 and ZM21 alloys and found that this alloy had good corrosion resistance and non-toxicity. However, the range of $\mathrm{Ca}$ contents involved in the above investigations is limited, and the corrosion mechanism of alloys with different $\mathrm{Ca}$ contents remains unclear.

This paper aimed to investigate the influence of a wide range of $\mathrm{Ca}$ additions on the microstructure, mechanical properties, corrosion resistance, and corrosion mechanisms of ZM21 alloys.

\section{Experimental}

Pure Mg (99.95 wt\%), pure zinc (99.70 wt\%), $\mathrm{Mg}-30 \% \mathrm{Ca}$, and $\mathrm{Mg}-3.9 \% \mathrm{Mn}$ master alloys were prepared as raw materials. Experimental alloys with different $\mathrm{Ca}$ additions were melted in a 60-kW electric resistance furnace. During melting, a commercially available refining agent was added to serve as a surface protective covering. After holding at $750{ }^{\circ} \mathrm{C}$ for $20 \mathrm{~min}$, the melt was cooled down to $720{ }^{\circ} \mathrm{C}$ and then cast into a steel mold for air cooling. After homogenization at $400{ }^{\circ} \mathrm{C}$ for $10 \mathrm{~h}$ and machining into an 82-mm-diameter cylinder, the alloys were extruded into 16-mm-diameter bars at $350{ }^{\circ} \mathrm{C}$. The extrusion speed was about $1.6 \mathrm{~mm} / \mathrm{s}$.

The chemical composition of the alloys, as shown in Table 1, was measured by X-ray fluorescence spectrometry (XRF-1800 CCDE). Optical microscopy (OM, OLYMPUSLEXT OLS4000) was used for metallographic observation, and scanning electron microscope (SEM, TESCAN

Table 1 Actual composition of experimental alloys (wt\%)

\begin{tabular}{lllllll}
\hline Alloys & $\mathrm{Zn}$ & $\mathrm{Ca}$ & $\mathrm{Mn}$ & $\mathrm{Fe}$ & $\mathrm{Si}$ & $\mathrm{Mg}$ \\
\hline \#1 (ZM21) & 2.02 & - & 0.94 & 0.02 & 0.05 & $\mathrm{Bal}$. \\
\#2 (ZM21 + 0.1Ca) & 2.13 & 0.09 & 1.05 & 0.03 & 0.04 & $\mathrm{Bal}$ \\
\#3 (ZM21 + 0.3Ca) & 2.09 & 0.33 & 0.99 & 0.02 & 0.02 & Bal. \\
\#4 (ZM21 + 0.7Ca) & 1.96 & 0.69 & 1.07 & 0.01 & 0.04 & Bal. \\
\#5 (ZM21 + 1.6Ca) & 2.01 & 1.58 & 0.93 & 0.04 & 0.06 & Bal. \\
\hline
\end{tabular}

VEGA 3 LMH) with an Oxford INCA Energy 350 energy dispersive X-ray spectrometer was used for microstructural observation. Grain size was measured by linear intercept method. Phase analyses were carried out via differential scanning calorimetry (DSC, METTLERTGA/DSC I$1100 \mathrm{LF}$ ) and X-ray diffraction (XRD, RIGAKU D/Max2500PC) with a $\mathrm{Cu}$ target. Specimens with $8 \mathrm{~mm}$ in diameter and $56 \mathrm{~mm}$ in gage length were used for tensile testing via an electronic universal testing machine (CMT5105). Three times were repeated for each sample. The percentage elongation after fracture was calculated according to "GB/T 228.1-2010." Before the tensile test, sample was marked every $5 \mathrm{~mm}$ at the middle range of gauge length. The overall length of marking is $50 \mathrm{~mm}$. Then, the sample was pieced together after fracture, where the changed marked length was measured as $L$.

The percentage elongation $(\%)=((L-50) / 50) \times 100$.

The corrosion behavior of the alloys was measured in $3.5 \mathrm{wt} \% \mathrm{NaCl}$ solution at approximately $25^{\circ} \mathrm{C}$ via electrochemical test and immersion tests. The exposure area of the electrochemical test was $10 \mathrm{~mm} \times 10 \mathrm{~mm}$, and the area of sample for weight loss tests was $10 \mathrm{~mm} \times 10 \mathrm{~mm} \times 10 \mathrm{~mm}$. Prior to test, all samples were wet ground with up to $2000 \mathrm{SiC}$ abrasive paper. The electrochemical corrosion tests were performed on a Metrohm Autolab PGSTAT 302 electrochemical workstation consisting of three electrodes: a saturated calomel cathode as the reference electrode, a Pt plate as the counter electrode, and the specimen as the working electrode. The polarization curves was tested from the -2000 to the $-1300 \mathrm{mV}$ with a scan rate of $0.001 \mathrm{~V} / \mathrm{s}$. Nova software was used to fit the polarization curves via the leastsquares fitting method. Electrochemical impedance spectroscopy (EIS) was performed by PGSTAT 302 electrochemical work station, and the frequency was from 100 to $0.01 \mathrm{~Hz}$. The EIS results were fitted to equivalent circuits by ZSimpWin software. Specimens for the weight loss test were immersed in $3.5 \mathrm{wt} \% \mathrm{NaCl}$ solution for $72 \mathrm{~h}$, and cleaned with distilled water. Then, a chromic acid bath with $200 \mathrm{~g} / \mathrm{L} \mathrm{CrO}_{3}+2 \mathrm{~g} / \mathrm{L} \mathrm{AgNO}_{3}$ was used to remove corrosion products of alloys, and dried in air for the weight loss measurement.

\section{Results}

\subsection{Microstructures}

The morphologies of the alloys are shown in Fig. 1. Alloys with $\mathrm{Ca}$ added show refined grains in comparison with 


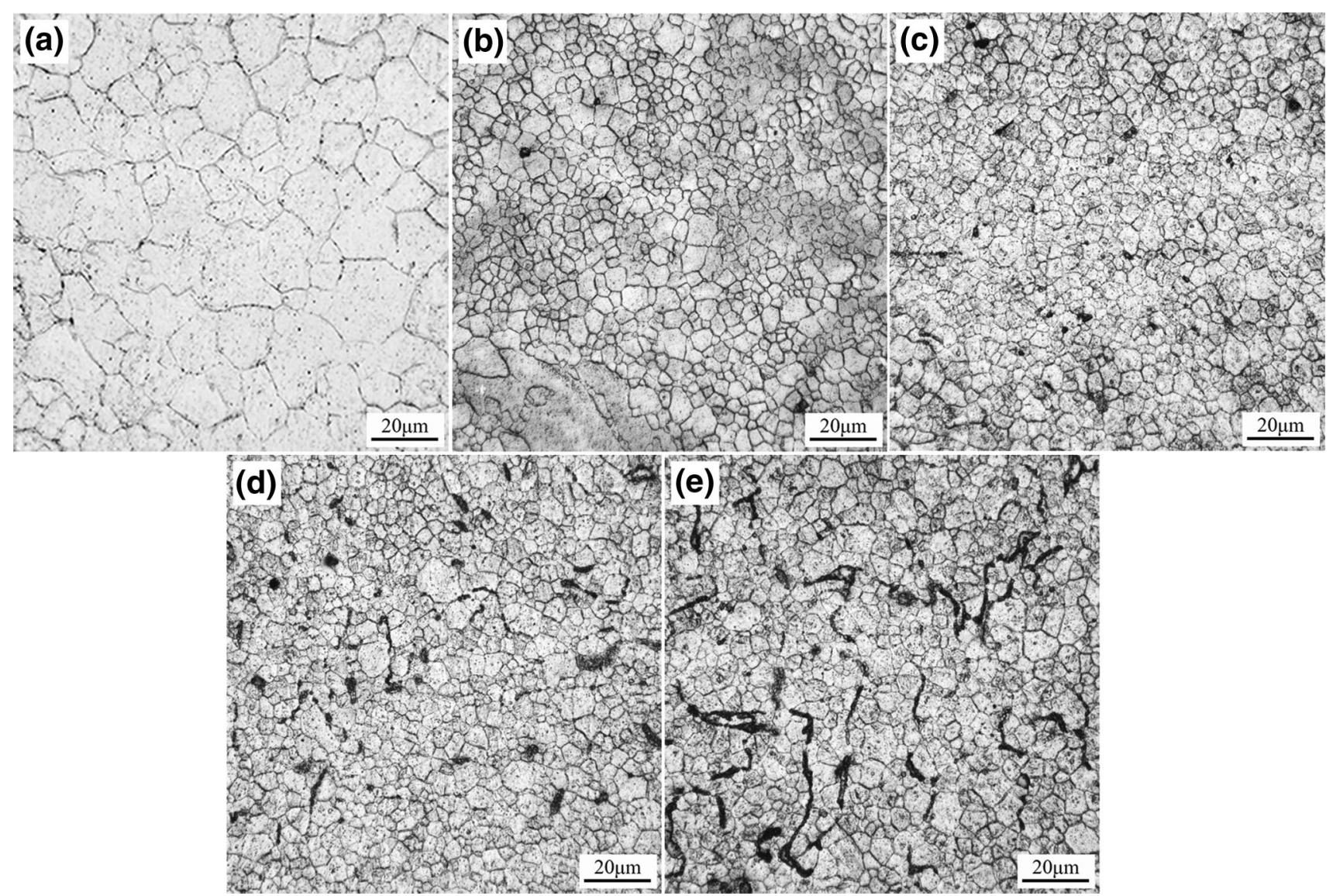

Fig. 1 Optical images of the alloys: a alloy \#1; b alloy \#2; $\mathbf{c}$ alloy \#3; d alloy \#4; $\mathbf{e}$ alloy \#5

alloy \#1. In contrast to the average grain size of alloy \#1 of $12.1 \mu \mathrm{m}$, the grain sizes of the other alloys decrease to 4.4 , $3.8,3.7$, and $3.5 \mu \mathrm{m}$, respectively, according to their different $\mathrm{Ca}$ contents. When the Ca content exceeds $0.3 \mathrm{wt} \%$, as in alloys \#3, \#4, and \#5, the grain size is no longer be refined despite of increases in Ca content. Hirai et al. [21] and Zhang et al. [22] also reported that Ca played a significant role in the grain refinement of magnesium alloys. Due to the slow diffusion of $\mathrm{Ca}$, composition undercooling formed in front of liquid-solid interface, which could restrict the grain growth and promoted the nucleation during solidification $[23,24]$. Therefore, the grain size of alloy decreased gradually by $\mathrm{Ca}$ addition. However, with more $\mathrm{Ca}$ addition, the solubility of $\mathrm{Ca}$ was saturated and this refinement effect would no longer work [21]. Moreover, the volume fraction of secondary phases, which distribute on the grain boundaries, increases with $\mathrm{Ca}$ addition. Most of the second phases in alloy \#4 are particulate shapes and contain $\mathrm{Mg}, \mathrm{Ca}$, and $\mathrm{Zn}$ elements, as shown in Fig. 2c. When the Ca content increases to $1.6 \mathrm{wt} \%$, as in alloy \#5, several second phases with strip shapes appear. These strip phases are intermetallic compounds only containing $\mathrm{Mg}$ and $\mathrm{Ca}$ elements.
Heating curves from DSC tests are shown in Fig. 3. Alloys \#1 and \#2 (with $0.1 \mathrm{wt} \%$ Ca addition) show a single evident exothermic peak. With increasing Ca content (as in alloys \#3, \#4, and \#5), a new exothermic peak appears at about $410{ }^{\circ} \mathrm{C}$, and the intensity of this peak increases. When the content of Ca reaches $1.6 \mathrm{wt} \%$ (as in alloy \#5), another exothermic peak appears at $470{ }^{\circ} \mathrm{C}$. The XRD patterns of the alloys are shown in Fig. 4. The $\alpha-\mathrm{Mg}$ and $\alpha$ $\mathrm{Mn}$ are observed in alloy 1\#. The diffraction peak of the $\mathrm{Ca}_{2} \mathrm{Mg}_{6} \mathrm{Zn}_{3}$ phase can be found in alloys with $\mathrm{Ca}$ content exceeding $0.3 \mathrm{wt} \%$ (as in alloys \#3, \#4, and \#5). Such a $\mathrm{Ca}_{2} \mathrm{Mg}_{6} \mathrm{Zn}_{3}$ phase has been observed in previous studies on the as-cast $\mathrm{Mg}-\mathrm{Zn}-\mathrm{Ca}$ alloys [25-28], and it was suggested that another $\mathrm{Ca}_{2} \mathrm{Mg}_{5} \mathrm{Zn}_{13}$ particles also exists by the analysis of XRD and SEM [29, 30]. Sun et al. [31] studied both the as-cast and as-extruded $\mathrm{Mg}-4 \mathrm{Zn}-0.2 \mathrm{Ca}$ alloy; the result of TEM showed that the particles in extruded alloy were confirmed to be $\mathrm{Ca}_{2} \mathrm{Mg}_{6} \mathrm{Zn}_{3}$, which was agreed with most previous studies. Therefore, Ca-containing phase here can be confirmed to be $\mathrm{Ca}_{2} \mathrm{Mg}_{6} \mathrm{Zn}_{3}$. However, the $\mathrm{Ca}_{2} \mathrm{Mg}_{6} \mathrm{Zn}_{3}$ phases are not found in the XRD result of alloy \#2 because of the limited $\mathrm{Ca}$ content in the sample. Oh-ishiet al. [32] reported the as-extruded $\mathrm{Mg}-\mathrm{Zn}-\mathrm{Ca}-\mathrm{Ag}$ alloy with trace 

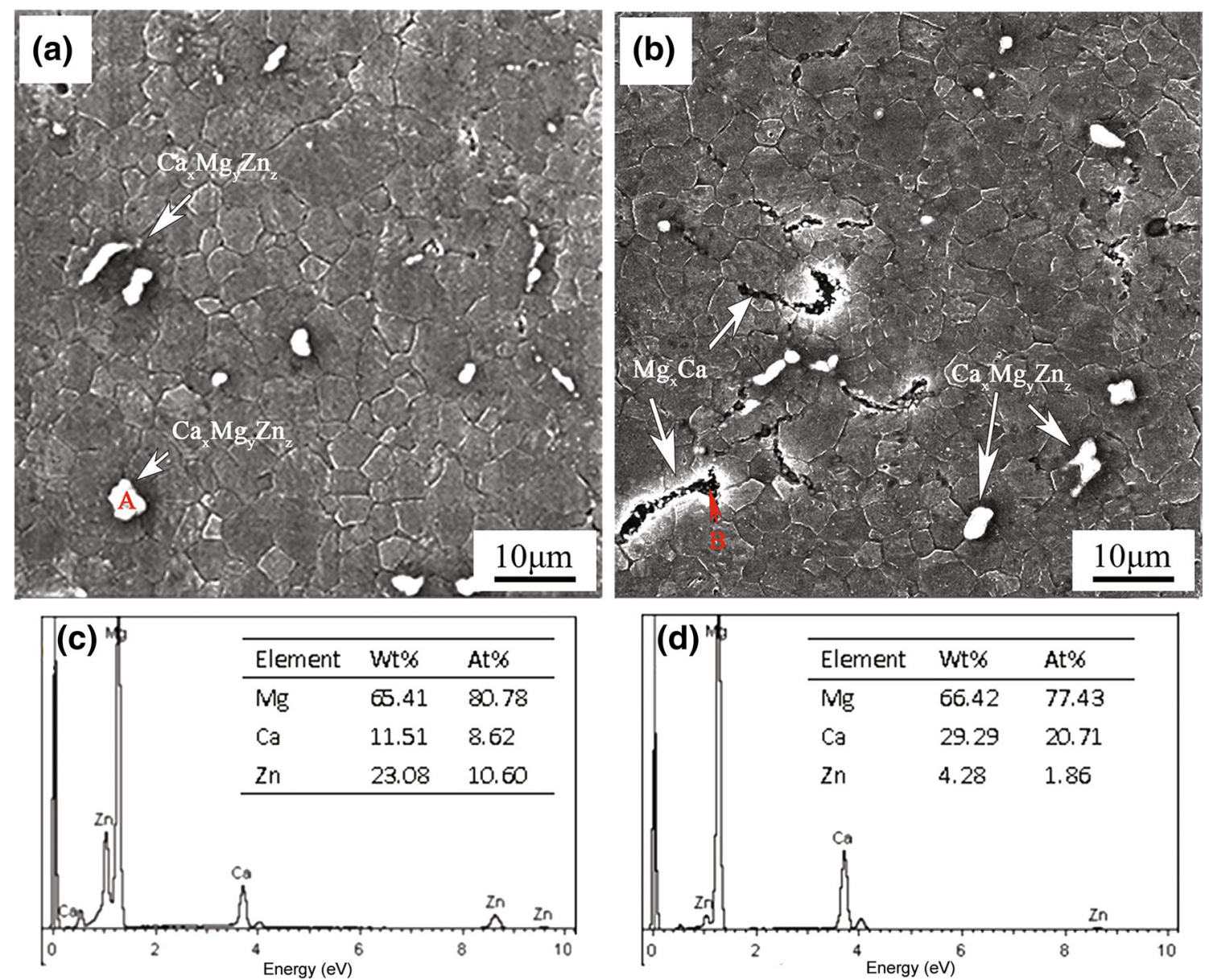

Fig. 2 SEM images and EDS patterns of the alloys: $\mathbf{a}$ alloy \#4; $\mathbf{b}$ alloy \#5; $\mathbf{c}$ EDS spectrum of the point A in $\mathbf{a} ; \mathbf{d}$ EDS spectrum of the point B in $\mathbf{b}$

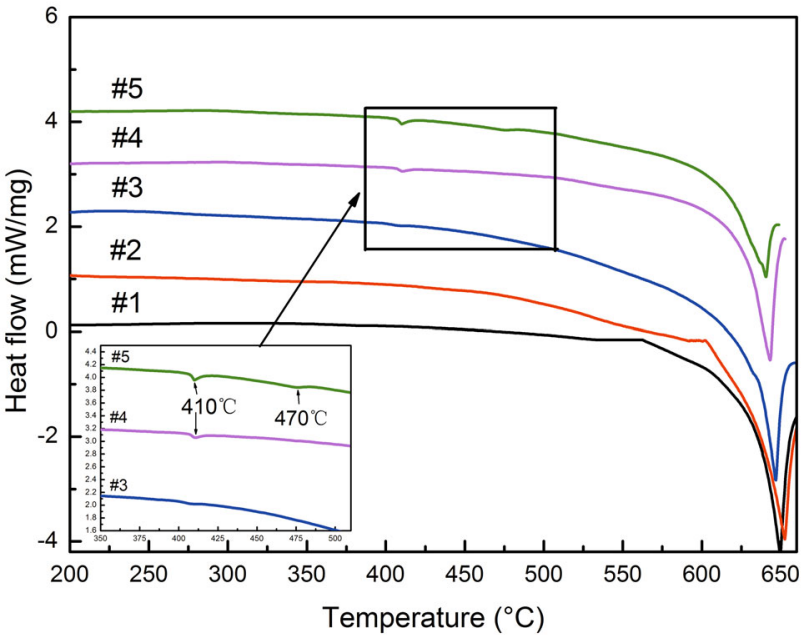

Fig. 3 DSC heating curves of the alloys

addition of $\mathrm{Ca}(0.1$ at.\%), the results of TEM showed that there was no Ca-containing particles appeared. Homma et al. [33] also reported that the presence of little $\mathrm{Ca}$ in $\mathrm{Mg}-$

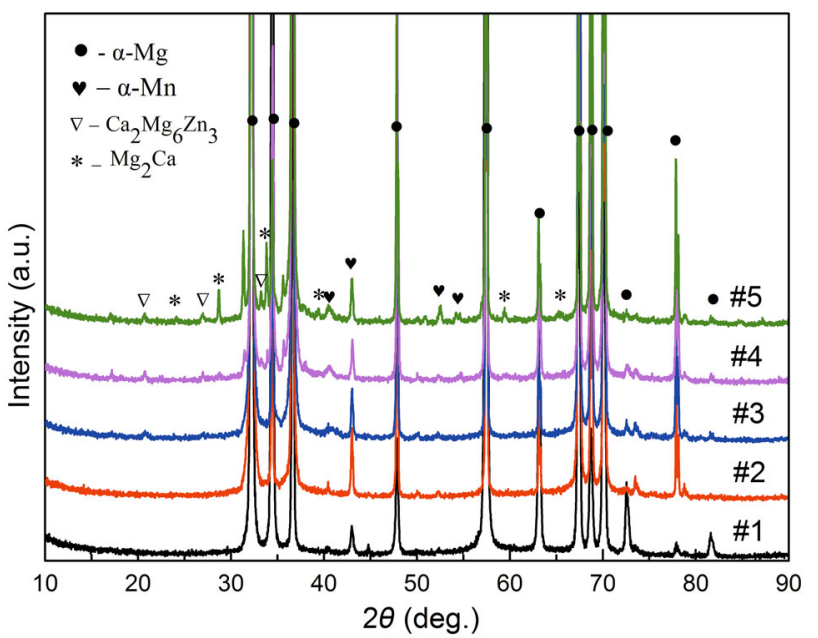

Fig. 4 X-ray diffraction patterns of the alloys

$6 \mathrm{Zn}-0.8 \mathrm{Zr}$ alloy helped to refine the intermetallic particles, rather than to form Ca-containing phases. This phenomenon has been reported in AM60 alloy with $0.5 \mathrm{wt} \%$ 
Ca addition by Kondori and Mahmudi [34], revealing that new phase did not form but the $\beta-\mathrm{Mg}_{17} \mathrm{Al}_{12}$ phase became more discontinuous. The maximums solubility of $\mathrm{Ca}$ in the magnesium alloy at room temperature was $<0.2 \mathrm{wt} \%$ [18], so it is probable that the $\mathrm{Ca}$ atoms are dissolved in the $\mathrm{Mg}$ matrix. When Ca content reaches $1.6 \mathrm{wt} \%$ (alloy \#5), the diffraction peak of $\mathrm{Mg}_{2} \mathrm{Ca}$ appears.

According to the above analysis, alloy \#1 is composed of $\alpha-\mathrm{Mg}$ and a small amount of $\alpha-\mathrm{Mn}$. Alloy \#2 has the same phase compound with alloy \#1, and there is no $\mathrm{Ca}_{2}$ $\mathrm{Mg}_{6} \mathrm{Zn}_{3}$ observed. Both alloys \#3 and \#4 possess $\mathrm{Ca}_{2}$ $\mathrm{Mg}_{6} \mathrm{Zn}_{3}$ granular phases in the grain interior or at the grain boundary. Alloy \#5 consists of not only $\mathrm{Ca}_{2} \mathrm{Mg}_{6} \mathrm{Zn}_{3}$ and $\alpha$ Mn but also $\mathrm{Mg}_{2} \mathrm{Ca}$ in the $\alpha-\mathrm{Mg}$ matrix. These results are identical to the previous research on $\mathrm{Mg}-\mathrm{Zn}-\mathrm{Ca}$ ternary alloys by Larionova et al. [11] and Oh-ishi et al. [35]. Only when $\mathrm{Ca}$ addition is enough and the $\mathrm{Zn} / \mathrm{Ca}$ ratio is $<1.2$, $\mathrm{Mg}_{2} \mathrm{Ca}$ phases can be formed, as in alloy \#5, which has a $\mathrm{Zn} / \mathrm{Ca}$ atomic ratio of 0.78 . Alloys \#3 and \#4 have $\mathrm{Zn} / \mathrm{Ca}$ atomic ratio of 3.9 and 1.7, respectively, there is no enough $\mathrm{Ca}$ to form $\mathrm{Mg}_{2} \mathrm{Ca}$ phases and only the $\mathrm{Ca}_{2} \mathrm{Mg}_{6} \mathrm{Zn}_{3}$ phases can be found in alloys. However, when the $\mathrm{Ca}$ addition is so low that all $\mathrm{Ca}$ dissolve in $\mathrm{Mg}$ matrix, no Ca-containing phases can be found.

\subsection{Mechanical Properties}

The mechanical performances of the alloys at room temperature are shown in Fig. 5 and Table 2. Addition of Ca to the ZM21 alloy facilitates grain refinement to achieve a small average grain size (AGS). The ultimate strength (UTS), yield strength (YS), and elongation (EL) are also improved to some extent by $\mathrm{Ca}$ addition. With the increase in $\mathrm{Ca}$, the UTSs of alloys have no obvious changes compared with the YS and the EL. When the $\mathrm{Ca}$ addition

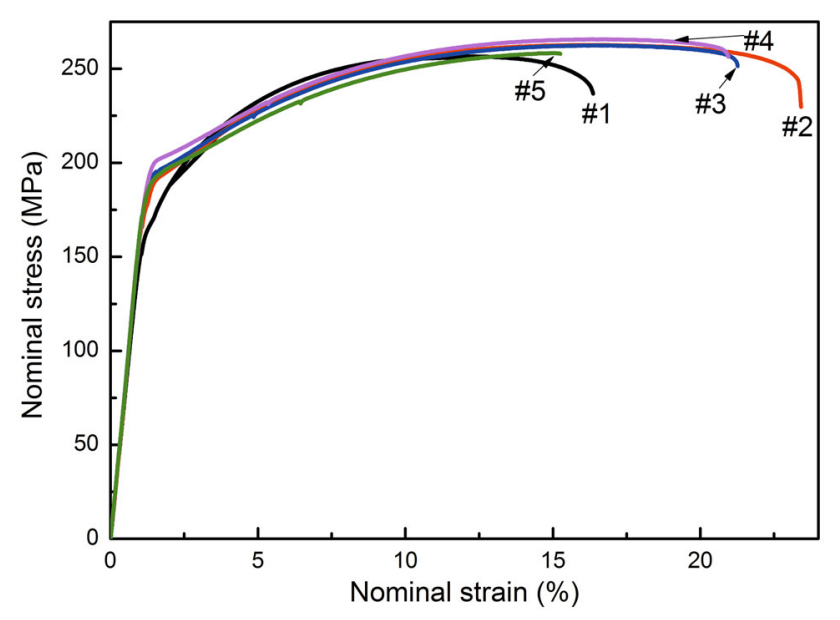

Fig. 5 Typical nominal stress-strain curves of alloys with different $\mathrm{Ca}$ addition exceeded $0.3 \mathrm{wt} \%$, the mechanical performance of the alloys begins to deteriorate. The UTS, YS, and EL decrease dramatically in alloy \#5 with $1.6 \mathrm{wt} \% \mathrm{Ca}$ additions, and the value of elongation is even lower than that of alloy \#1.

The SEM morphologies of tensile fracture surfaces of alloys with different $\mathrm{Ca}$ contents are shown in Fig. 6. The obvious dimples were observed in all alloys, which indicate ductile fracture characteristics, and the alloys demonstrate significant plastic deformation prior to fracturing. Addition of $\mathrm{Ca}$ to alloys produces more numerous toughening dimples. However, the increase in $\mathrm{Ca}$ content (from 0.1-0.7 wt \%) does not lead to obvious change in the density of toughening dimples, which means that the elongation of alloys remains the same. When the Ca content reaches $1.6 \mathrm{wt} \%$, as in alloy \#5, strip intermetallic compounds (Fig. 6e) with sharp corners are observed and the ductility of the alloy decreases significantly.

\subsection{Corrosion Behavior}

The polarization curves and the related data of the alloys tested in $3.5 \mathrm{wt} \% \mathrm{NaCl}$ solutions are shown in Fig. 7 and Table 3. The corrosion potentials of Ca-containing alloys are not significantly different from that of ZM21 alloy (alloy \#1). At the same potential in the cathodic beside of polarization curves, the current densities of $\mathrm{Ca}$-containing alloys are lower than that of alloy \#1, indicating that alloys with $\mathrm{Ca}$ addition own the lower cathodic hydrogen evolution rate. The lower the hydrogen evolution rate, the slower the corrosion reaction rate. In addition, corrosion current densities of Ca-containing alloys initially decrease with increasing $\mathrm{Ca}$ content and then increase rapidly. When $0.7 \mathrm{wt} \% \mathrm{Ca}$ addition, alloy \#4 has the lowest current density; while the Ca content increases to $1.6 \mathrm{wt} \%$, alloy \#5 is the highest. Aloy \#4 possesses the lower corrosion current density and the highest polarization resistance with the value of $39.74 \mu \mathrm{A} / \mathrm{cm}^{2}$ and $411.85 \Omega \mathrm{cm}^{2}$, respectively, showing the good corrosion resistance.

The results of immersion tests conducted in $3.5 \mathrm{wt} \%$ $\mathrm{NaCl}$ solution for $72 \mathrm{~h}$ are shown in Fig. 8. The average weight loss of three samples of each alloy decreases with increasing $\mathrm{Ca}$ content $(\leq 0.7 \mathrm{wt} \%)$, and it increases rapidly when $1.6 \mathrm{wt} \% \mathrm{Ca}$ is added. This finding is consistent with the trend of current density observed in the polarization curves. When the Ca content is $0.7 \mathrm{wt} \%$, as in alloy \#4, the alloy exhibits a minimum average weight loss of $0.77 \mathrm{mg} /$ $\left(\mathrm{cm}^{2}\right.$ days), showing the best corrosion resistance in all alloys.

With $0.7 \mathrm{wt} \% \mathrm{Ca}$ adding to ZM21 alloy, alloy \#4 shows the good corrosion resistance with the lowest current density and weight loss. When the addition of $\mathrm{Ca}$ is more like $1.6 \mathrm{wt} \%$, the corrosion resistance of alloy is worse than that of alloy with no $\mathrm{Ca}$ addition. In order to study the 
Table 2 Specific data of mechanical properties of alloys

\begin{tabular}{lllllc}
\hline Alloy & Ca $(\mathrm{wt} \%)$ & UTS $(\mathrm{MPa})$ & YS $(\mathrm{MPa})$ & EL $(\%)$ & $15.2 \pm 0.8$ \\
\hline$\# 1$ & 0 & $251 \pm 1.9$ & $157 \pm 3.9$ & $22.2 \pm 1.3$ & AGS $(\mu \mathrm{m})$ \\
$\# 2$ & 0.09 & $262 \pm 1.1$ & $188 \pm 2.5$ & $19.6 \pm 0.7$ & 4.4 \\
$\# 3$ & 0.33 & $265 \pm 4.2$ & $200 \pm 5.1$ & $21.5 \pm 0.7$ & 3.8 \\
$\# 4$ & 0.69 & $260 \pm 1.8$ & $187 \pm 4.7$ & $14.6 \pm 1.5$ & 3.7 \\
\hline 5
\end{tabular}
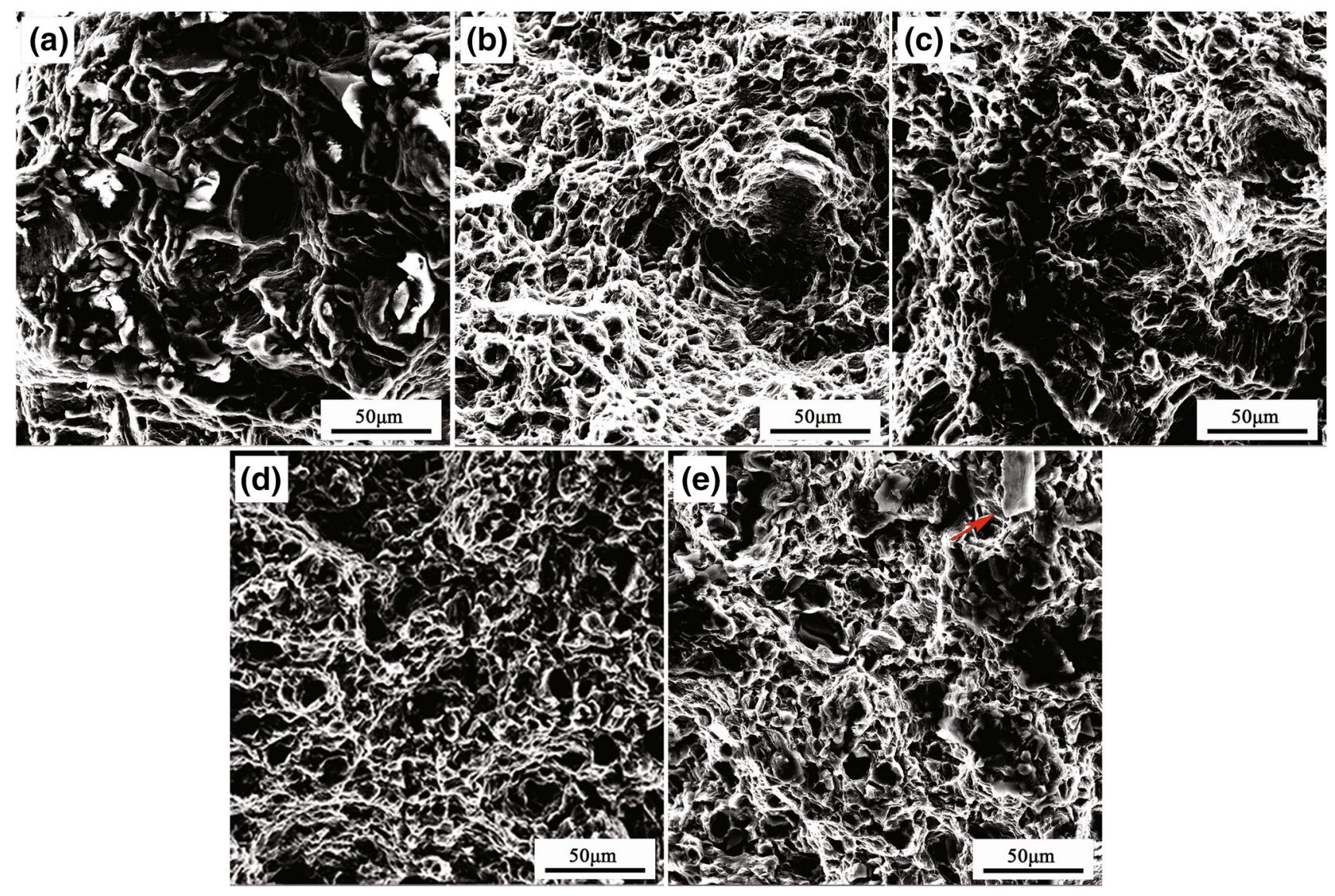

Fig. 6 SEM morphology of tensile fracture surfaces for alloys \#1 a, alloy \#2 b, alloy \#3 c, alloy \#4 d, alloy \#5 e

corrosion process of alloys \#1, \#4, and \#5, SEM images of the corroded surfaces are shown in Fig. 9a-c, respectively. Magnified images of the corrosion products on the surfaces of alloys \#4 and \#5 are shown in Fig. 9d-f. The EDS analysis results shown in Table 4 reveal that the corrosion products are mainly composed of $\mathrm{O}, \mathrm{Mg}$, and $\mathrm{Cl}$. This finding indicates that chloride ions also participate in the corrosion reaction. After soaking in $3.5 \mathrm{wt} \% \mathrm{NaCl}$ solution for $48 \mathrm{~h}$, the surfaces of the alloys could be divided into two regions: a black seemingly uncorroded substrate and a region covered by a white corrosion product layer. The corrosion products formed on top of the black substrate increase with increasing addition of $\mathrm{Ca}$. When the content of $\mathrm{Ca}$ addition is $1.6 \mathrm{wt} \%$, practically the entire alloy surface is covered by corrosion products, which begins to form into a large block, as shown in Fig. 9e.

To further investigate the effect of $\mathrm{Ca}$ on the corrosion resistance and mechanism of the alloys, the electrochemical impedance of alloys \#1, \#4, and \#5 were measured. The Nyquist plot, Bode plot, and phase-angle diagram of these three alloys and the corresponding equivalent circuit used to model the EIS are shown in Fig. 10, and the related data are presented in Table 5. In the equivalent circuits obtained, $R_{\mathrm{s}}$ represents the solution resistance and CPE represents the constant-phase element used to compensate the non-homogeneity of the system $\left(\mathrm{CPE}_{1}\right.$ is related to the 


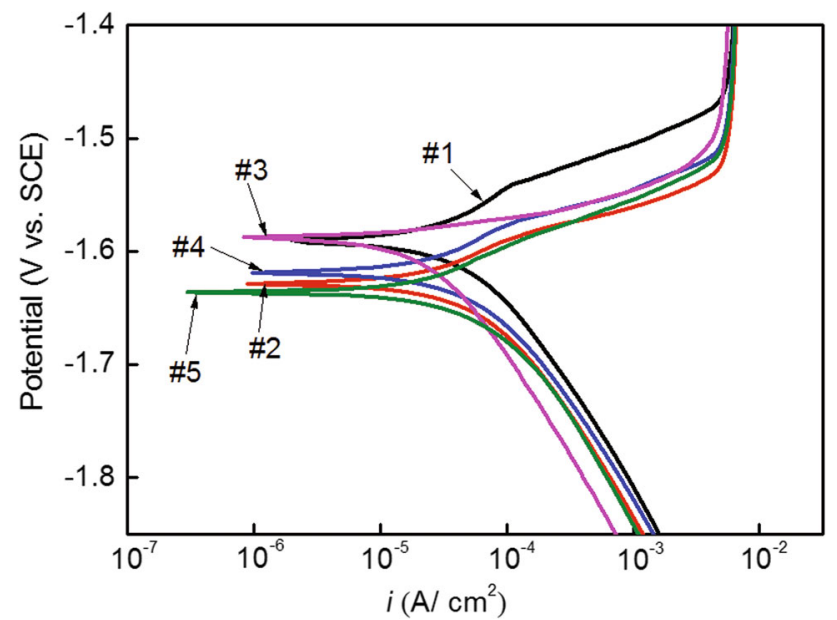

Fig. 7 Polarization curves of alloys in $3.5 \mathrm{wt} \% \mathrm{NaCl}$ solution

electric double layer at the interface of the oxide film, and the alloy substrate and $\mathrm{CPE}_{2}$ are related to the electric double layer at the interface of the electrolyte solution and the alloy substrate). $R_{\mathrm{f}}$ represents the film resistance, and $R_{\text {ct }}$ represents the charge transfer resistance. $L$ represents the inductance. The appearance of $L$ indicates that pitting corrosion occurs in these alloys.

The Nyquist plots of alloys contain two capacitance loops, and the shape of Nyquist plots has no change with the addition of $\mathrm{Ca}$. The radius of the largest loop curve in the Nyquist plots of alloys \#1, \#4, and \#5 (Fig. 10a) shows the order: $\# 4>\# 1>\# 5$, which means that the matrix of alloy \#4 exhibits considerably higher corrosion resistance than those of alloys \#1 and \#5. In the case of Bode plots $|Z|$-frequency curves (Fig. 10b), alloy \#4 also shows the higher impedance values from the high frequency to low frequency than alloys \#1 and \#5. The corrosion resistant of materials increases with the higher impedance values. As for the phase degree-frequency curves (Fig. 10c), there are two wave crests, which is one big in the middle frequency and a small crest in the low frequency, indicating the presence of two capacitance loops. The dissolution of the magnesium matrix can be characterized by the value of $R_{\mathrm{ct}}$. In general, a higher $R_{\mathrm{ct}}$ implies a lower dissolution rate. Alloy \#4, which possessed an $R_{\mathrm{ct}}$ of $1169.96 \Omega \mathrm{cm}^{2}$

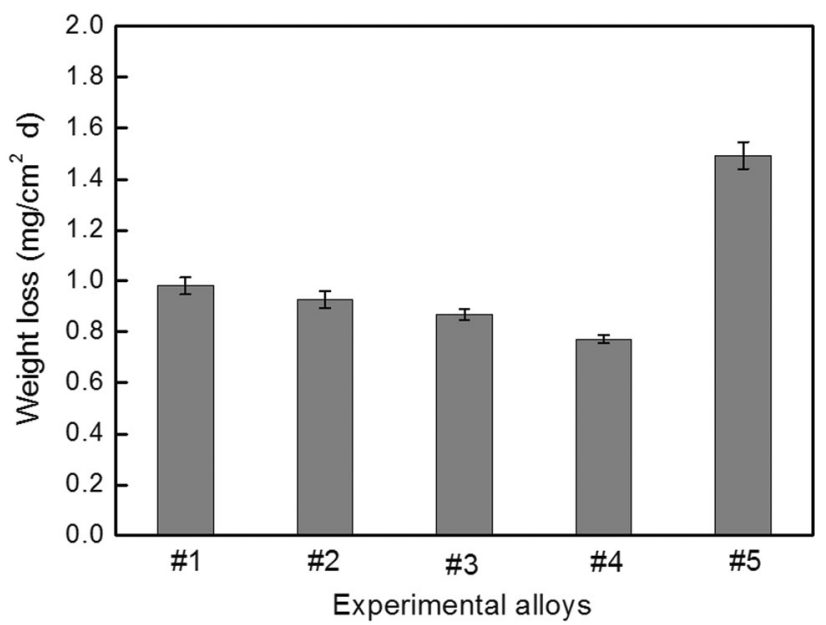

Fig. 8 Immersion results of alloys in $3.5 \mathrm{wt} \% \mathrm{NaCl}$ solution for $72 \mathrm{~h}$

(Table 5), exhibits the lowest matrix dissolution rate among the sample tests.

The corrosion resistant of an oxide film formed on the surface of the alloy sample can be characterized by both the second capacitive loop at the right portion of each Nyquist plot and the oxide film resistance $\left(R_{\mathrm{f}}\right)$. Higher $R_{\mathrm{f}}$ values indicate better surface protection, that is, the film on the surface of the alloy is difficult to be corroded [36]. The $R_{\mathrm{f}}$ of alloy \#4 (2242.04 $\Omega \mathrm{cm}^{2}$ ) is considerably higher than those of alloy \#1 $\left(421.71 \Omega \mathrm{cm}^{2}\right)$ and alloy \#5 $\left(235.87 \Omega \mathrm{cm}^{2}\right)$. Alloys \#4 and \#5 have the same equivalent circuit with alloy \#1, indicating that the $\mathrm{Ca}$ addition do not change the corrosion mechanism of alloy.

\section{Discussion}

\subsection{Mechanic Performance}

The effect of $\mathrm{Ca}$ on the strength of the alloys can be analyzed by the following mechanisms: grain refinement strengthening, solid solution strengthening, and secondphase strengthening [37, 38]. Owing to the limited content of $\mathrm{Ca}$ added to alloy \#2, no new phase containing $\mathrm{Ca}$ is found in this alloy, and the $\mathrm{Ca}$ atoms dissolve in $\mathrm{Mg}$ matrix

Table 3 Data of corrosion resistance of alloys in $3.5 \mathrm{wt} \% \mathrm{NaCl}$ solution

\begin{tabular}{llllll}
\hline Alloy & Corrosion potential $E_{\text {corr }}\left(V_{\text {SCE }}\right)$ & Current density $i_{\text {corr }}\left(\mu \mathrm{A} / \mathrm{cm}^{2}\right)$ & $b_{\mathrm{a}}(\mathrm{mV} /$ decade $)$ & $b_{\mathrm{c}}(\mathrm{mV} / \mathrm{decade})$ & $R_{\mathrm{p}}\left(\Omega \mathrm{cm}^{2}\right)$ \\
\hline$\# 1$ & -1.59 & 75.69 & 75.13 & 185.27 & 306.69 \\
$\# 2$ & -1.63 & 83.03 & 57.47 & 190.68 & 231.01 \\
$\# 3$ & -1.62 & 66.49 & 57.44 & 177.38 & 283.41 \\
$\# 4$ & -1.59 & 39.74 & 47.05 & 189.24 & 411.85 \\
$\# 5$ & -1.64 & 87.11 & 72.94 & 183.86 \\
\hline
\end{tabular}



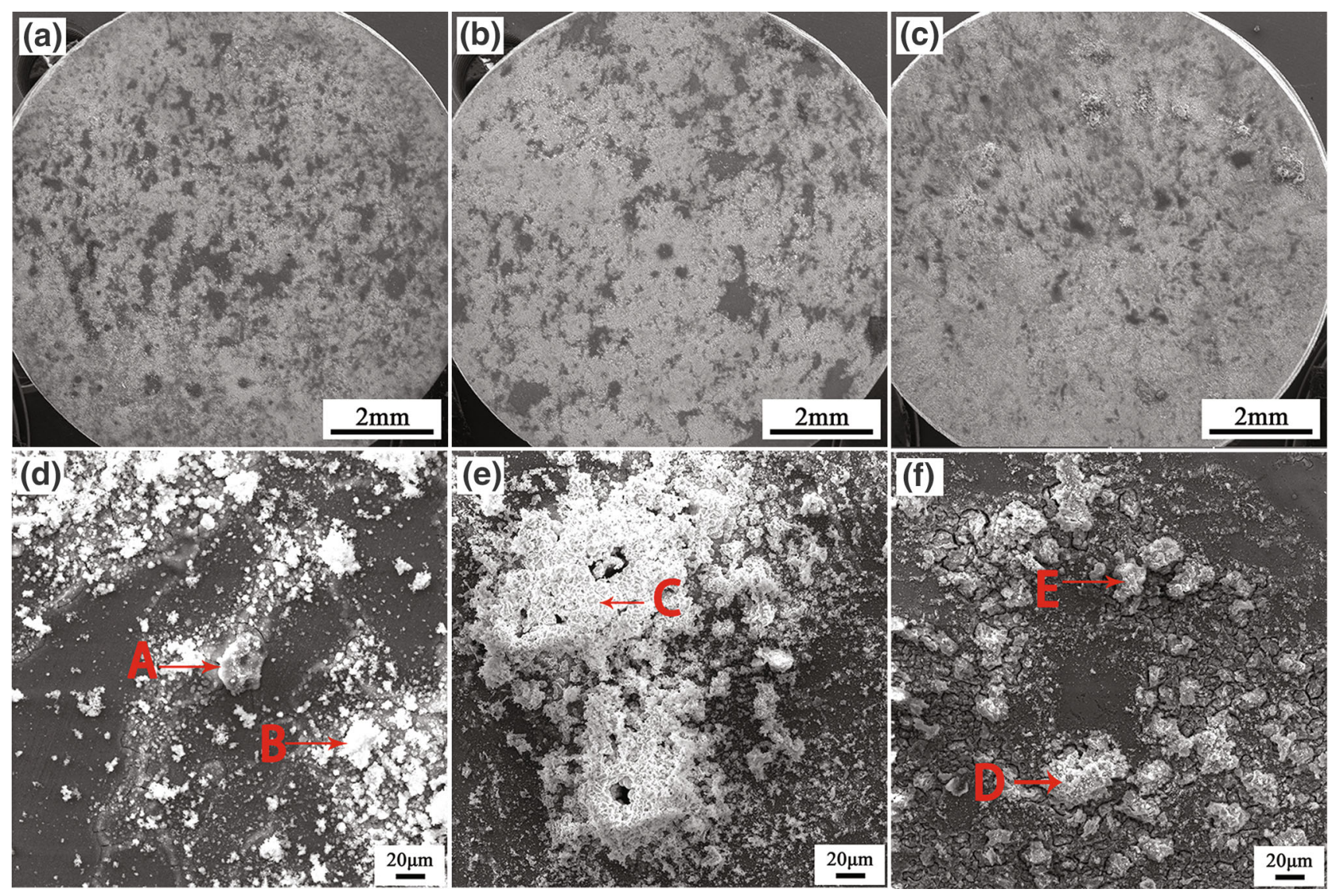

Fig. 9 SEM micrographs of alloys in $3.5 \mathrm{wt} \% \mathrm{NaCl}$ solution for $48 \mathrm{~h}$ a alloy \#1; b, $\mathbf{d}$ alloy \#4; c, e, f alloy \#5

Table 4 EDS results of corrosion products in alloys \#4 and \#5 (at.\%)

\begin{tabular}{lllll}
\hline Position & $\mathrm{O}$ & $\mathrm{Mg}$ & $\mathrm{Si}$ & $\mathrm{Cl}$ \\
\hline $\mathrm{A}$ & 55.0 & 41.7 & 2.0 & 1.3 \\
$\mathrm{~B}$ & 58.1 & 41.9 & - & - \\
$\mathrm{C}$ & 53.7 & 46.3 & - & - \\
$\mathrm{D}$ & 62.7 & 34.9 & - & 2.4 \\
E & 54.7 & 40.6 & - & 4.6 \\
\hline
\end{tabular}

completely. Thus, compared with alloy \#1, the strength improvement of alloy \#2 is attributed to grain refinement strengthening and solid solution strengthening. Alloy \#3 exhibits the effect of both solid solution strengthening because of the presence of more $\mathrm{Ca}$ in the solid solution and second-phase strengthening (Fig. 1). More $\mathrm{Ca}_{2} \mathrm{Mg}_{6} \mathrm{Zn}_{3}$ secondary phases prevent grain boundaries from migration by pinning after hot deformation, and the small precipitation particles can enhance alloy strength via the secondphase strengthening mechanism. Therefore, alloy \#3 exhibits superior strength in comparison with the other alloys. The second-phase strengthening is related to the volume fraction of precipitates and the diameter of precipitates: It increases with the increasing volume fraction and the decreasing diameter [39, 40]. The average diameter of $\mathrm{Ca}_{2} \mathrm{Mg}_{6} \mathrm{Zn}_{3}$ phase particles in alloy \#4 is exceeding $5 \mu \mathrm{m}$ (seen in Fig. 2). Large particles can serve as nucleation sites to induce $\mathrm{Ca}$ precipitation from matrix, resulting in decreases in solid solution strengthening and reductions in the availability of tiny particles for precipitation strengthening. It is well known that the microporous and cracks easily form around the coarse second phases, which disperse in the grains and boundaries [41]. The cracks grow and propagate during the deformation, leading to an adverse effect of strength [40]. Thus, alloy \#4 exhibits slightly lower strength than alloy \#3. With the increasing $\mathrm{Ca}$ addition in alloy \#5, large number of $\mathrm{Mg}_{2} \mathrm{Ca}$ phases form. They have features of long strip and a long size larger than $15 \mu \mathrm{m}$, causing stress concentration and brittle fractures during deformation. This phenomenon is also found by the Li et al. [42] and Fan et al. [43]. Previous studies showed that the strength and ductility decreased rapidly if the size of particle exceeded $10 \mu \mathrm{m}$ [44, 45].

Compared with that of alloy \#1, alloys \#2, \#3, and \#4 have an increase in percentage elongation, mainly because of grain refinement effect of $\mathrm{Ca}$ additions. However, increases in $\mathrm{Ca}$ content caused the elongation of alloy \#5 

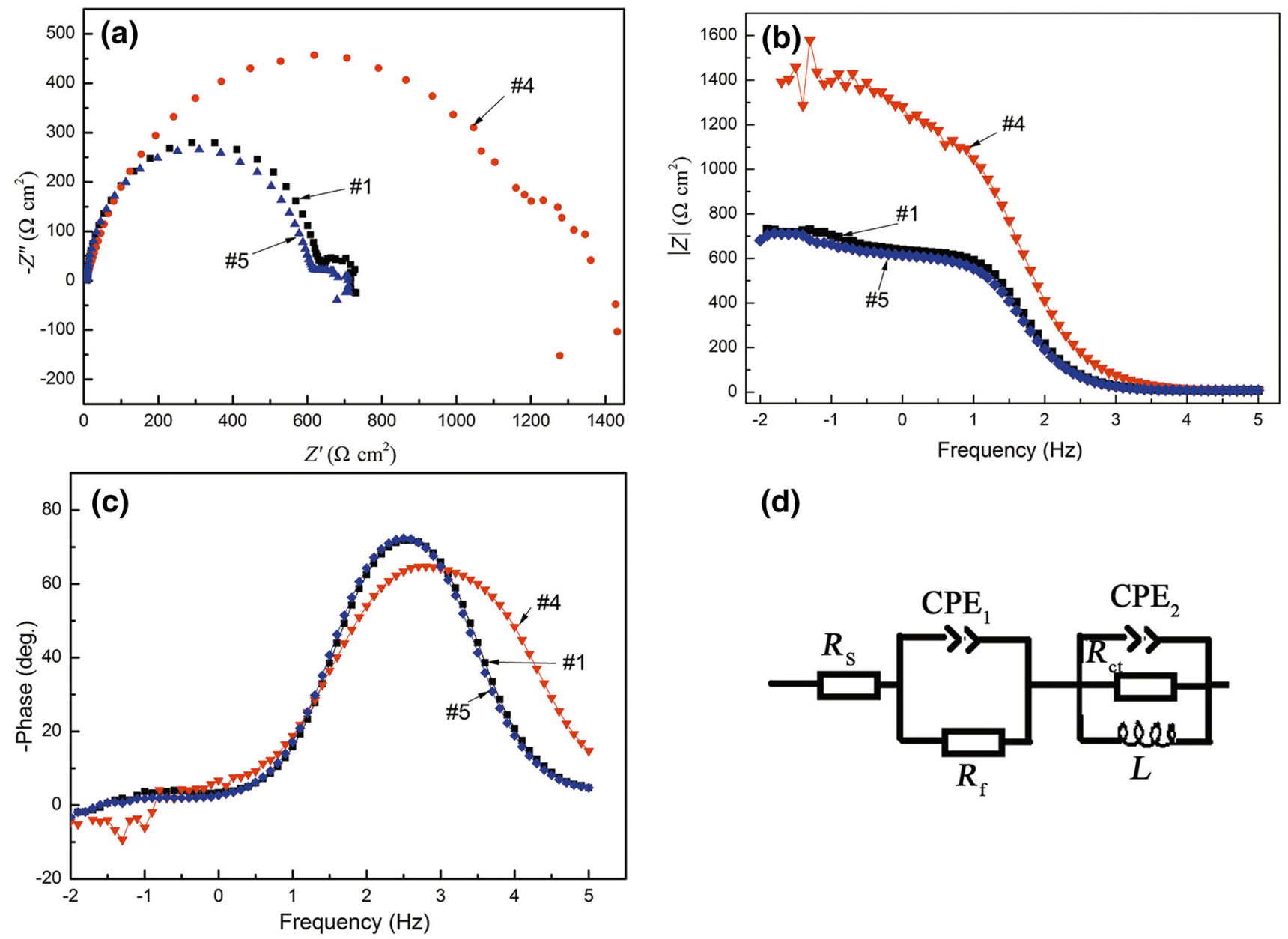

(d)

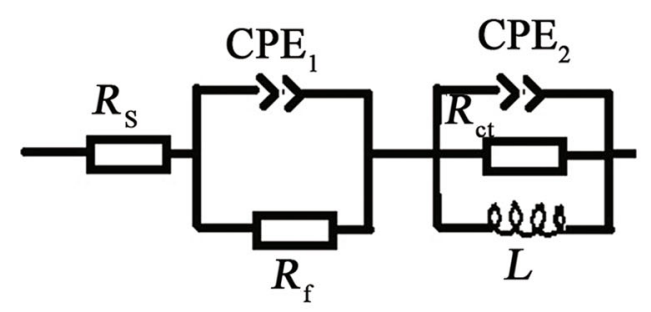

Fig. 10 Impedance plots and equivalent circuits of alloys \#1, \#4 and \#5: a Nyquist diagram of alloys; b Bode plots of alloys; c phase-angle diagram of alloys; $\mathbf{d}$ equivalent circuits of the EIS spectra

Table 5 Fitting results of the EIS spectra

\begin{tabular}{llllrlrrr}
\hline Alloy & $R_{\mathrm{s}}\left(\Omega \mathrm{cm}^{2}\right)$ & \multicolumn{1}{c}{$\mathrm{CPE}_{1}\left(\mu \Omega^{-1} \mathrm{~cm}^{-2} \mathrm{~s}^{-1}\right)$} & $n$ & $R_{\mathrm{f}}\left(\Omega \mathrm{cm}^{2}\right)$ & $\mathrm{CPE}_{2}\left(\mu \mathrm{F} \mathrm{cm}{ }^{-2}\right)$ & $R_{\mathrm{ct}}\left(\Omega \mathrm{cm}^{2}\right)$ & $n$ & $L\left(\mathrm{H} \mathrm{cm}{ }^{-2}\right)$ \\
\hline$\# 1$ & 7.35 & 11,490 & 0.44 & 421.71 & 10.34 & 600.73 & 0.95 & 1331 \\
$\# 4$ & 6.47 & 2262 & 0.56 & 2242.04 & 11.19 & 1169.96 & 0.82 & 5308 \\
$\# 5$ & 7.41 & 10,180 & 0.47 & 235.87 & 10.38 & 575.20 & 0.96 & 4679 \\
\hline
\end{tabular}

decreasing sharply for the formation of $\mathrm{Mg}_{2} \mathrm{Ca}$ phases. The $\mathrm{Mg}_{2} \mathrm{Ca}$ phases, which are segregated at the grain boundaries, appear, and the connection of the grains will be destroyed, leading to diminish alloy strength. The elongation of alloys \#3 and \#4 decreases slightly in comparison with that of alloy \#2, because of formation of a small amount of $\mathrm{Ca}_{2} \mathrm{Mg}_{6} \mathrm{Zn}_{3}$ phases at the grain boundaries. The formation of phases hinders the movement of grain boundaries during deformation at room temperature.

\subsection{Corrosion Behaviors}

The corrosion test was conducted in $3.5 \mathrm{wt} \% \mathrm{NaCl}$ solution to simulate the corrosion behavior of the alloys in a marine environment. The granular corrosion products shown in Fig. 9 are $\mathrm{Mg}(\mathrm{OH})_{2}$. The reaction equations are as follows [46, 47]:

$\mathrm{Mg}=\mathrm{Mg}^{2+}+2 \mathrm{e}^{-} \quad$ (anodic reaction),

$2 \mathrm{H}_{2} \mathrm{O}+2 \mathrm{e}^{-}=\mathrm{H}_{2} \uparrow+2 \mathrm{OH}^{-} \quad$ (cathodic reaction), 
$\mathrm{Mg}^{2+}+2 \mathrm{OH}^{-}=\mathrm{Mg}(\mathrm{OH})_{2} \downarrow$

(corrosion products formation).

$\mathrm{Cl}^{-}$ions react with $\mathrm{Mg}$, leading to a surface oxidation film to be ruptured easily and the $\mathrm{Mg}$ matrix dissolves quickly [48]. Polarization results can provide an indication of corrosion at a specific time points via the calculated current density [49]. The immersion results can markedly influence the galvanic effect between the $\mathrm{Mg}$ matrix and second phases. Both the electrochemical results and the immersion results indicate that the ZM21 alloy with 0.7 wt $\%$ $\mathrm{Ca}$ addition exhibits the lowest cathodic hydrogen evolution rate and weight loss among the experimental alloys. Unlike the polarization and immersion test results described above, the EIS results reveal some information regarding corrosion kinetics. As shown in Fig. 10d, the characteristics of the equivalent electric circuit of the ZM21 alloy are not changed by $\mathrm{Ca}$ addition.

The corrosion process is illustrated in Fig. 11. It is well known that an oxide layer of $\mathrm{MgO}$ (the blue layer on the

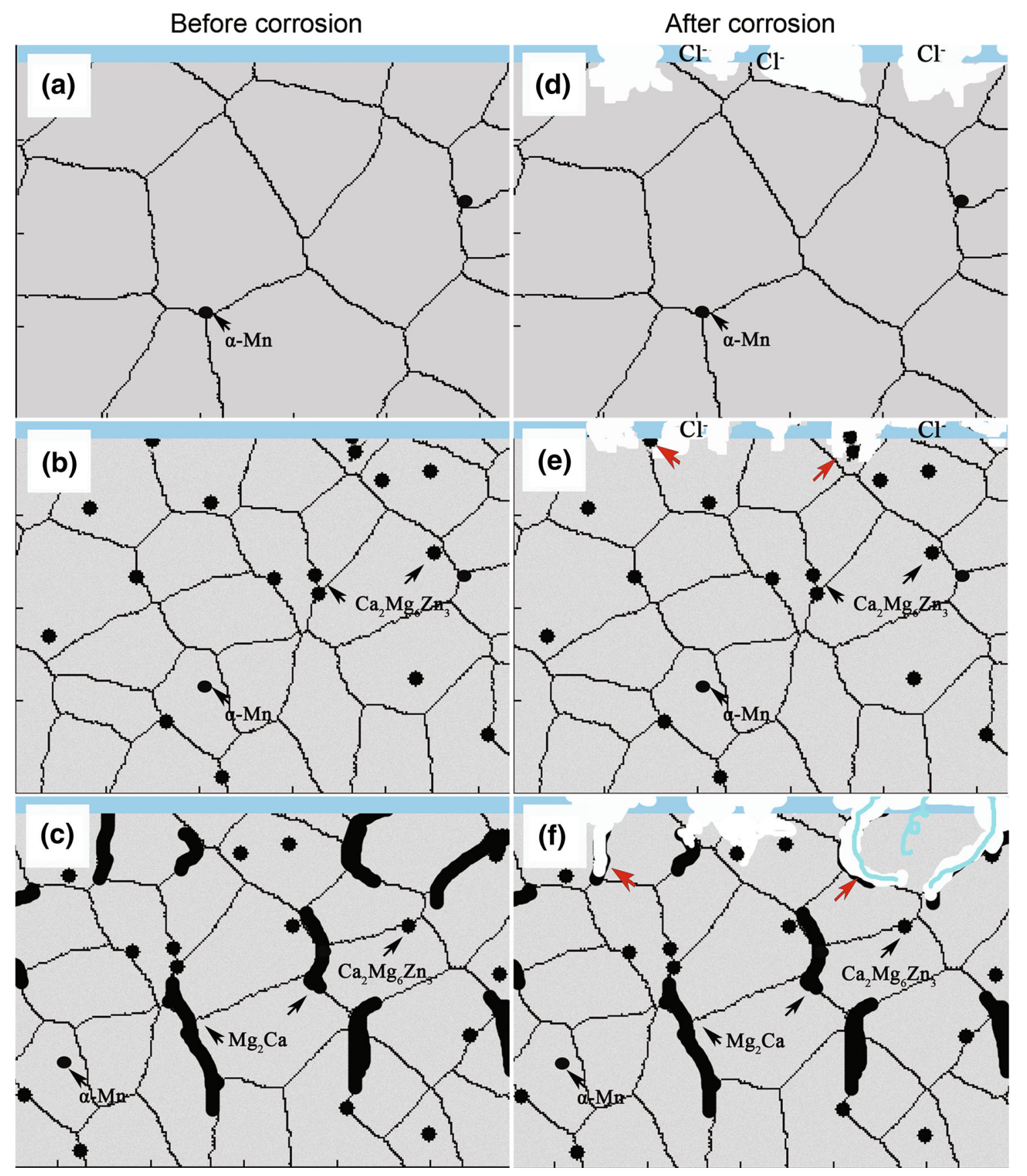

Fig. 11 Schematic illustration of experimental alloys before corrosion and after corrosion: a, $\mathbf{d}$ alloy \#1; b, e alloy \#4; c, f alloy \#5 
surface of the alloys in Fig. 11) is easy to form when magnesium contact humid air or water. This layer is prone to corrosion because of its porous structure. When the alloys are immersed in the $\mathrm{NaCl}$ solution, $\mathrm{MgO}$ initially reacts with water, according to the following equation:

$\mathrm{MgO}+\mathrm{H}_{2} \mathrm{O}=\mathrm{Mg}(\mathrm{OH})_{2}$.

The initial $\mathrm{Mg}(\mathrm{OH})_{2}$ film is compact and deposits on the surface of alloys. With the development of quick corrosion, $\mathrm{OH}^{-}$in $\mathrm{NaCl}$ solution combines with $\mathrm{Mg}^{2+}$ to form $\mathrm{Mg}$ hydroxide and the value of $\mathrm{PH}$ increases, resulting in the breakdown of the $\operatorname{Mg}(\mathrm{OH})_{2}$ protective film [50]. When certain parts of the surface film are broken and cracked, the matrix alloy begins to corrode intensely and the corrosion rate of the residual surface film decreases. Thus, certain areas of the surface film survive the corrosion test, as seen in the dark areas in the micrographs in Fig. 9.

As described above, $\mathrm{Mg}$ was easy to be corroded due to its lower potential compared with other metal (Fig. 11d), the corrosion products here are $\mathrm{Mg}(\mathrm{OH})_{2}$ and little $\mathrm{MgCl}_{2}$ [51, 52]. The ZM21 alloy (alloy \#1) is mainly composed of $\alpha-\mathrm{Mg}$ and a small amount of $\alpha-\mathrm{Mn}$. Among these components, the $\alpha-M g$ possesses the more negative corrosion potential $\left(-2.37 V_{\mathrm{SHE}}\right)$ than $\alpha-\mathrm{Mn}$, which has the potential of $-1.18 V_{\mathrm{SHE}}$. Thus, when galvanic corrosion occurs, $\mathrm{Mg}$ matrix acts as anode and directly suffers from corrosion (Fig. 11d), while the $\alpha$-Mn acts as the cathode.

When sufficient content of $\mathrm{Ca}$ is added, the grains become refined and the $\mathrm{Ca}_{2} \mathrm{Mg}_{6} \mathrm{Zn}_{3}$ phases, which exhibit higher potential compared with $\alpha-\mathrm{Mg}$, are generated [53]. The $\mathrm{Ca}_{2} \mathrm{Mg}_{6} \mathrm{Zn}_{3}$ phases play a role of cathode, and the $\alpha$ $\mathrm{Mg}$ acts as the anode to be corroded. The fine-grained microstructure can improve the corrosion resistance of the alloy, because the large number of grain boundaries can be used as a physical barrier to block the path of corrosion solution [54, 55]. Alvarez-Lopez et al. [56] reported that the corrosion performance of AZ31 was significantly improved when grain size decreased to $4.5 \mu \mathrm{m}$. The second phases have a significant influence on $\mathrm{Mg}$ corrosion. It is said that second phases have two effects on the corrosion of Mg: On one hand, when the second phases are small size and discretely distributed in grains, they act as microcathodes to accelerate the corrosion of $\alpha-\mathrm{Mg}$. On the other hand, when second phases are more and coarse, they can act as obstacle to hinder the propagation of corrosion. Alloy \#4 has the refined grains with size of $4.4 \mu \mathrm{m}$ and more $\mathrm{Ca}_{2} \mathrm{Mg}_{6} \mathrm{Zn}_{3}$ phases, which can inhibit the corrosion path of $\alpha-\mathrm{Mg}$, as shown in Fig. 11e, and finally shows good corrosion resistance.

However, with addition of an excess $\mathrm{Ca}$ amount, such as $1.6 \mathrm{wt} \%$, the $\mathrm{Mg}_{2} \mathrm{Ca}$ phases form and the alloy now is compound of $\alpha-\mathrm{Mg}, \mathrm{Ca}_{2} \mathrm{Mg}_{6} \mathrm{Zn}_{3}$ and $\mathrm{Mg}_{2} \mathrm{Ca}$. $\mathrm{Mg}_{2} \mathrm{Ca}$ distributed at grain boundaries, galvanic corrosion occurred between $\mathrm{Mg}_{2} \mathrm{Ca}$ phases, and $\mathrm{Mg}$. Südholz et al. [57] studied the corrosion potential of $\mathrm{Mg}$ and $\mathrm{Mg}_{2} \mathrm{Ca}$ phases in $0.1 \mathrm{~mol} / \mathrm{L} \mathrm{NaCl}$ solution, and the results showed that the $\mathrm{Mg}_{2} \mathrm{Ca}$ phases $\left(-1.75 V_{\mathrm{SCE}}\right)$ have more negative potential than $\mathrm{Mg}\left(-1.65 V_{\mathrm{SCE}}\right)$. So, $\mathrm{Mg}_{2} \mathrm{Ca}$ acts as anode suffering from corrosion, and the $\alpha-\mathrm{Mg}$ acts as the cathode. When galvanic corrosion occurs in $\mathrm{Ca}_{2} \mathrm{Mg}_{6} \mathrm{Zn}_{3}$ and $\mathrm{Mg}_{2} \mathrm{Ca}$, the $\mathrm{Mg}_{2} \mathrm{Ca}$ phase acts as the most easily corroded phase (anode) in the alloy and the $\mathrm{Ca}_{2} \mathrm{Mg}_{6} \mathrm{Zn}_{3}$ acted as cathode by the report of Bakhsheshi-Rad et al. [58] and Jang et al. [51]. After the big strip of $\mathrm{Mg}_{2} \mathrm{Ca}$ is corroded, the solution easily initiates corrosion pitting at the interior of alloy (marked by the red arrow in Fig. 11f).Thus, the corrosion reaction reaches deeper inside of the alloy. Moreover, as certain parts of the $\mathrm{Mg}$ matrix are surrounded by $\mathrm{Mg}_{2} \mathrm{Ca}$ phases, once the $\mathrm{Mg}_{2} \mathrm{Ca}$ phases are corroded and the corrosion products are dissolved, the entire $\alpha-\mathrm{Mg}$ grain can fall off the matrix owing to the lost support provided by $\mathrm{Mg}_{2} \mathrm{Ca}$ phases, which previously exist in the matrix.
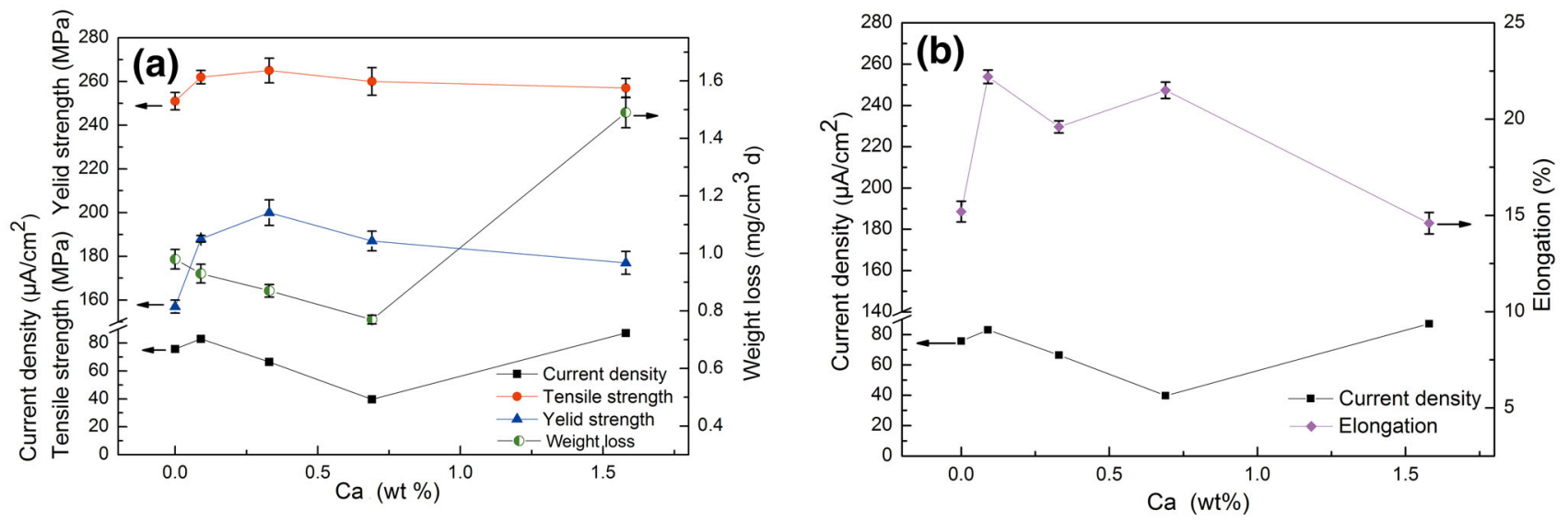

Fig. 12 a Corrosion current density, weight loss, yield strength and tensile strength change with the different Ca additions; $\mathbf{b}$ elongation and corrosion current density change with the different $\mathrm{Ca}$ additions 
Therefore, corrosion can be accelerated by the appearance of $\mathrm{Mg}_{2} \mathrm{Ca}$ phases in the alloy with high $\mathrm{Ca}$ addition.

\subsection{Performance Comparison}

According to the corrosion and mechanical properties of alloys with different $\mathrm{Ca}$ addition (Fig. 12), ZM21 with $\mathrm{Ca}$ contents of $0.7 \mathrm{wt} \%$ shows the best corrosion resistance. The next best-performing alloys are those with Ca contents of 0.3 and $0.1 \mathrm{wt} \%$; alloy with $1.6 \mathrm{wt} \% \mathrm{Ca}$ shows the poorest results. However, the mechanical performance of alloys modified with $\mathrm{Ca}$ addition is superior to that of the ZM21 alloy, except when excess $\mathrm{Ca}$ is added. Considering overall improvements in mechanical performance and corrosion resistance, the alloy with $0.7 \mathrm{wt} \% \mathrm{Ca}$ addition shows the best characteristics, which possessed a tensile strength of $260 \mathrm{MPa}$, yield strength of $187 \mathrm{MPa}$, elongation of $21.5 \%$ and average weight loss of $0.77 \mathrm{mg} /$ ( $\mathrm{cm}^{2}$ days).

\section{Conclusions}

1. Grain refinement results from $\mathrm{Ca}$ addition to $\mathrm{ZM} 21$ alloy. The mechanical performance of the alloys is improved through solid solution strengthening, second-phase strengthening, and the grain refinement strengthening effect of $\mathrm{Ca}$ addition.

2. Corrosion resistance is improved with $\mathrm{Ca}$ addition for the grain refinement and formation of $\mathrm{Ca}_{2} \mathrm{Mg}_{6} \mathrm{Zn}_{3}$ phases, which hindering extensive $\alpha-\mathrm{Mg}$ matrix corrosion. Addition of excess $\mathrm{Ca}$, such as $1.6 \mathrm{wt} \%$, results in formation of $\mathrm{Mg}_{2} \mathrm{Ca}$ phases, which weakened both the mechanical performance and corrosion resistance of the alloy.

3. The alloy with the best overall properties was achieved with $0.7 \mathrm{wt} \% \mathrm{Ca}$ addition. This alloy yielded a tensile strength of $260 \mathrm{MPa}$, elongation of $21.5 \%$, and average weight loss of $0.77 \mathrm{mg} /\left(\mathrm{cm}^{2}\right.$ days $)$.

Acknowledgments This work was supported by the National Natural Science Foundation of China (No. 51474043), the Ministry of Education of China (NSRFDR 20130191110018), and the Education Commission of Chongqing Municipality (KJZH14101).

\section{References}

[1] A.A. Luo, J. Magnes. Alloys 1, 2 (2013)

[2] G.L. Shi, D.F. Zhang, Q.W. Dai, Trans. Nonferrous Met. Soc. China 18, 59 (2008)

[3] M. Thirumurugan, G.M. Thirugnasambandam, S. Kumaran, T. Srinivasa, Trans. Nonferrous Met. Soc. China 21, 2154 (2011)
[4] R.C. Zeng, L.J. Liu, T.T. Pang, F. Zhang, W.W. Zhang, S.Q. Li, H.Z. Cui, E.H. Han, Acta Metall. Sin. (Engl. Lett.) 28, 373 (2015)

[5] Y.C. Zhao, G.S. Huang, G.G. Wang, T.Z. Han, F.S. Pan, Acta Metall. Sin. (Engl. Lett.) 28, 1387 (2015)

[6] J. Liao, M. Hotta, Y. Mori, Mater. Sci. Eng., A 544, 10 (2012)

[7] J. Chen, J.Q. Wang, E.H. Han, W. Ke, D.W. Shoesmith, Acta Metall. Sin. (Engl. Lett.) 29, 1 (2016)

[8] J. Yan, J. Peng, E.A. Nyberg, F.S. Pan, Appl. Surf. Sci. 369, 92 (2016)

[9] A. Atrens, G.L. Song, F.Y. Cao, Z.M. Shi, P.K. Bowen, J. Magnes. Alloys 1, 177 (2013)

[10] X.M. Zong, D. Wang, W. Liu, K.B. Nie, C.X. Xu, J.S. Zhang, Acta Metall. Sin. (Engl. Lett.) 29, 32 (2016)

[11] T.V. Larionova, W.W. Park, B.S. You, Scr. Mater. 45, 7 (2001)

[12] D.M. Kang, J.O. An, J.S. Kwak, J. Mater. Sci. 11, 843 (2010)

[13] R.Q. Hou, C.Q. Ye, C.D. Chen, S.G. Dong, M.Q. Lv, S. Zhang, J.S. Pan, G.L. Song, C.J. Lin, Acta Metall. Sin. (Engl. Lett.) 29, 46 (2016)

[14] J. Luo, H. Yan, N. Zheng, R.S. Chen, Acta Metall. Sin. (Engl. Lett.) 29, 205 (2016)

[15] A.K. Chaubey, B.B. Jha, B.K. Mishra, Acta Metall. Sin. (Engl. Lett.) 28, 444 (2015)

[16] K. Su, K.K. Deng, F.J. Xu, H.B. Nie, L. Zhang, X. Zhang, W.J. Li, Acta Metall. Sin. (Engl. Lett.) 28, 1015 (2015)

[17] H. Somekawa, M. Toshi, Mater. Sci. Eng., A 459, 366 (2007)

[18] B. Zhang, Y. Wang, L. Geng, C. Lu, Mater. Sci. Eng., A 539, 56 (2012)

[19] J. Hofstetter, M. Becker, E. Martinelli, A.M. Weinberg, B. Mingler, H. Kilian, S. Pogatscher, P.J. Uggowitzer, J.F. Löffler, JOM 66, 566 (2014)

[20] E.L. Zhang, L. Yang, Mater. Sci. Eng., A 497, 111 (2008)

[21] K. Hirai, H. Somekawa, Y. Takigawa, K. Higashi, Mater. Sci. Eng., A 403, 276 (2005)

[22] L. Zhang, K.K. Deng, K.B. Nie, F.J. Xu, K. Su, W. Liang, Mater. Sci. Eng., A 636, 279 (2015)

[23] D. Xiao, Z. Chen, X. Wang, M.J. Zhang, D. Chen, Mater. Sci. Eng., A 660, 166 (2016)

[24] S. Liu, G. Yang, W. Jie, Acta Metall. Sin. (Engl. Lett.) 27, 1134 (2014)

[25] L.B. Tong, M.Y. Zheng, L.R. Cheng, D.P. Zhang, S. Kamado, J. Meng, H.J. Zhang, Mater. Charact. 104, 66 (2015)

[26] Y.Z. Du, X.G. Qiao, M.Y. Zheng, K. Wu, S.W. Xu, Mater. Des. 85, 549 (2015)

[27] Y. Lu, A.R. Bradshaw, Y.L. Chiu, I.P. Jones, Mater. Sci. Eng., A 48, 480 (2015)

[28] Z. Xu, C. Smith, S. Chen, J. Sankar, Mater. Sci. Eng., B 176, 1660 (2011)

[29] Y. Pan, S. He, D. Wang, D. Huang, T. Zheng, S. Wang, P. Dong, C. Chen, Mater. Sci. Eng., C 47, 85 (2015)

[30] C.J. Li, H.F. Sun, X.W. Li, J.L. Zhang, W.B. Fang, Z.Y. Tan, J. Alloys Compd. 652, 122 (2015)

[31] Y. Sun, B. Zhang, Y. Wang, L. Geng, X. Jiao, Mater. Des. 34, 58 (2012)

[32] K. Oh-ishi, C.L. Mendis, T. Homma, S. Kamado, T. Ohkubo, K. Hono, Acta Mater. 57, 5593 (2009)

[33] T. Homma, C.L. Mendis, K. Hono, S. Kamado, Mater. Sci. Eng., A 527, 2356 (2010)

[34] B. Kondori, R. Mahmudi, Mater. Sci. Eng., A 527, 2014 (2010)

[35] K. Oh-ishi, R. Watanabe, C.L. Mendis, K. Hono, Mater. Sci. Eng., A 526, 177 (2009)

[36] B. Homayun, A. Afshar, J. Alloys Compd. 607, 1 (2014)

[37] F. Li, W. Shi, N. Bian, H.B. Wu, Acta Metall. Sin. (Engl. Lett.) 28, 649 (2015)

[38] Q.S. Yang, B. Jiang, Z.J. Yu, Q.W. Dai, S.Q. Luo, Acta Metall. Sin. (Engl. Lett.) 28, 1257 (2015) 
[39] J.F. Nie, Scr. Mater. 48, 1009 (2003)

[40] G.S. Hu, D.F. Zhang, T. Tang, X. Shen, L.Y. Jiang, J.Y. Xu, F.S. Pan, Mater. Sci. Eng., A 634, 5 (2015)

[41] Q.Z. Peng, H.T. Zhou, F.H. Zhong, H.B. Ding, X. Zhou, R.R. Liu, T. Xie, Y. Peng, Mater. Des. 66, 566 (2015)

[42] Y. Li, P.D. Hodgson, C. Wen, J. Mater. Sci. 46, 365 (2010)

[43] Y. Fan, G.H. Wu, H.T. Gao, C.Q. Zhai, Y.P. Zhu, Trans. Nonferrous Met. Soc. China 15, 210 (2005). in Chinese

[44] S.H. Park, J.G. Jung, J. Yoon, B.S. You, Mater. Sci. Eng., A 626, $128(2015)$

[45] Z.T. Jiang, B. Jiang, H. Yang, Q.S. Yang, J.H. Dai, F.S. Pan, J. Alloys Compd. 647, 357 (2015)

[46] Q. Liu, W.L. Cheng, H. Zhang, C.X. Xu, J.S. Zhang, J. Alloys Compd. 590, 162 (2014)

[47] J.F. Wang, Y. Li, S. Huang, X.E. Zhou, Appl. Surf. Sci. 317, 1143 (2014)

[48] X. Zhang, Y.J. Li, K. Zhang, C.S. Wang, H.W. Li, M.L. Ma, B.D. Zhang, Trans. Nonferrous Met. Soc. China 23, 1226 (2013)

[49] A. Pardo, M.C. Merino, A.E. Coy, R. Arrabal, F. Viejo, E. Matykina, Corros. Sci. 50, 823 (2008)
[50] X. Zhang, K. Zhang, X.G. Li, X. Deng, H.W. Li, B.D. Zhang, C.S. Wang, Trans. Nonferrous Met. Soc. China 22, 1018 (2012)

[51] Y. Jang, Z. Tan, C. Jurey, Z. Xu, Z. Dong, B. Collins, Y. Yun, J. Sankar, Mater. Sci. Eng., C 48, 28 (2015)

[52] H.R. Bakhsheshi-Rad, M.H. Idris, M.R. Abdul-Kadir, A. Ourdjini, M. Medraj, M. Daroonparvar, E. Hamzah, Mater. Des. 53, 283 (2014)

[53] H.R.B. Rad, M.H. Idris, M.R.A. Kadir, S. Farahany, Mater. Des. 33, 88 (2012)

[54] R.C. Zeng, L. Sun, Y.F. Zheng, Corros. Sci. 79, 69 (2014)

[55] Z. Pu, G.L. Song, S. Yang, J.C. Outeiro, O.W. Dillon Jr., D.A. Puleo, I.S. Jawahir, Corros. Sci. 57, 192 (2012)

[56] M. Alvarez-Lopez, M.D. Pereda, J.A. del Valle, M. FernandezLorenzo, M.C. Garcia-Alonso, O.A. Ruano, M.L. Escudero, Acta Biomater. 6, 1763 (2010)

[57] A.D. Südholz, N.T. Kirkland, R.G. Buchheit, N. Birbilis, Electrochem. Solid State Lett. 14, C5 (2011)

[58] H.R. Bakhsheshi-Rad, M.R. Abdul-Kadir, M.H. Idris, S. Farahany, Corros. Sci. 64, 184 (2012) 